\title{
UNIQUENESS IN TRANSLATING ARABIC HAGIOGRAPHY OF SHAIKH 'ABD AL-QĀDIR AL-JAILĀNĪ: THE CASE OF AN-NŪR AL-BURHĀN̄̄
}

\author{
Abdul Munip \\ UIN Sunan Kalijaga, Yogyakarta, Indonesia \\ abdul.munip@uin-suka.ac.id
}

First received: 14 September 2017

Final proof received: 31 January 2018

\begin{abstract}
In Indonesia, the hagiographical book of Shaikh 'Abd al-Qādir al-Jailānī has many versions of translation. One of it is an-Nūr al-burhānī, a Javanese translation by Kyai Muslih al-Marāqī. Unlike other Javanese translations, an-Nür al-burhān̄i is not merely a translation but can be considered a new book, in which the translator added some new information and opinion in it. Therefore, the book is interesting to be investigated deeply to find scientific information about the content of the book, the technique, method, and ideology of translation that are adopted and applied by the translator. Using content analysis, the study finds that the book consists of al-Jailānī's journey of life, his miracles and teachings. The other findings prove that the translator has implemented various techniques of translation such as calque, borrowing, description, amplification-addition, and adaptation techniques. The translator has tried to make the TT (Target Text) easy to be understood by Javanese people, but he tends to apply literal (linguistic transcodification) method rather than interpretative-communicative (translation of the sense) method. As a result, the TT is still influenced by the structure of Arabic as SL (Source Text) and not natural in everyday use of Javanese language. Thus, it can be inferred that the translator more dominantly adopts the ideology of foreignization than domestication. However, what the translator does is more advanced than the other Javanese translators, who usually use only the word for word or literal translation method. This is the uniqueness in translating al-Jailān̄̄ss hagiography or manāqib.
\end{abstract}

Keywords: Arabic hagiography; al-Jailānī; translation technique; translation method; translation ideology

Indonesia as a country with Muslims as the majority has rich Islamic literature. The literature includes various branches of Islamic knowledge, like aqĩdah (the Islamic theology), 'ulüm al-Qur'ān (the sciences of Koran), 'ulüm al-hadith (the sciences of prophet traditions), fiqh (the Islamic law), tașawwuf (the Islamic mysticism), târih Islām (the history of Islam), and so on. Based on its language, the literature can be divided into three categories, i.e. the Arabic language books, the translated books from Arabic, and the books using Indonesian or local languages. Besides that, there is a large amount of Islamic literature written in adapted Arabic script known as Pegon (Fikri, 2014), although the language used is not Arabic.

The rich literature has been influencing both the intellectuality and religious practices of Indonesian Muslims, because of its functions as sources and references for their daily lives. Most of primary Islamic literature is learned in various Islamic educational institutions, like Islamic boarding houses (pesantren), Islamic schools (madrasah), and public lectures (majelis taklim). Besides its function as a source of Islamic teachings, some literature has double functions, i.e. as a source of Islamic teachings and as a tool of religious rituals. One type of such literature is the hagiographical book talking about the narrative miracles of prominent figures who take a special position in the heart of Indonesian Muslims. The figures may be the Prophet Muhammad himself, the Prophet's companions, Muslim saints, and 'ulemas (Esposito, 2017).

The most popular hagiography is about Prophet Muhammad that has two versions, i.e., Mawlid ad-diba' $\bar{c}$, the work of Shaikh 'Abd arRaḥmān ad-Dibā'̄i (866-944 AH/1461-1537 CE) and 'Iqd al-jawhar fi mawlid an-nabiy al-azhār, the work of Shaikh Ja'far al-Barzanjī (1126-1177 AH/1714-1764 CE) a Muslim writer from Madinah, the city of Prophet Muhammad (Najih, 1997). Both of the books are popular among Indonesian traditional Muslims, since they are recited in celebrating the birthday of Prophet Muhammad or other religious events and ritual. Because of the popularity of the two authors, the religious ritual involving the reading of both books is known as Barzanjen, if the book read in the ritual is the work of al-Barzanjī, or Diba'an if the book read in the ritual is the work of ad-Dibā' $\overline{1}$. In fact, both of the books are compiled in one publication entitled Majmū'āt mawlid ar-rasūl, so people can choose which book they want to read.

The other hagiography is about the most popular Sufi master (saint) in Indonesia, Shaikh 'Abd al-Qādir al-Jailānī, although he is not an Indonesian Muslim. He lived in Baghdad, Iraq, 1077-1166 CE (Al-Gailani, 2016; Al-Kailān̄̄, 2014). 
At least, 70 Arabic hagiographical books talking about him can be found (Ad-Duhaibi, 2007, pp. 711). One of those is a work of al-Barzanji entitled al-Lujain ad-dān̄ fì dhikr nubdhah min manāqib ash-Shaikh 'Abd al-Qādir al-Jailānī. This book was written approximately in $1763 \mathrm{AD}$ and immediately gained reputation especially among followers of tarekat (Sufis brotherhood), like Tarekat QadiriyahNaqsyabandiyah (TQN) in Indonesia. The name of this tarekat refers to the name of 'Abd al-Qādir himself as the founder (van Bruinessen, 2000).

The popularity of al-Lujain ad-dānī is proved by many translation versions of the book in Indonesian, such as Lubāb al-ma' 'ānì fi tarjamat allujain ad-dāni fi manāqib ash-Shaikh 'Abd al-Qādir al-Jailān̄ (Javanese translation) by Abi Shaleh Mustamir Kudus; Jauhar al-asnāni 'alā al-lujain ad-dāni fi manāqib 'Abd al-Qādir al-Jailān̄ (Javanese translation) by Abdul Hamid Kendal; AnNūr al-burhān̄̄ fì tarjamat al-lujain ad-dāni by Muslih al-Marāqi Demak; an-Nail al-amān̄i (Javanese translation) by Ahmad Subki Masyhadi Pekalongan; Khulāṣah al-manāqib li ash-Shaikh 'Abd al-Qādir al-Jailān̄̄ (Javanese translation) by Asrori Ahmad Tempuran Magelang; Manaqib Syaikh Abdul Qadir al-Jailani makna Jawa Pegon $\&$ terjemah Indonesia (Javanese and Indonesian translation) by Ahmad Sunarto; Penuntun manaqib Syeikh Abdul Qodir al-Jailani dengan terjemah (Indonesian translation) by Baidlowi Syamsuri; Terjemah manaqib Syaikh Abdul Qadir al-Jailani (Indonesian translation) by Moh Saifulloh Al-Azis; and Wawacan Kangjeng Syaikh Abd al-Qadir Jilani $R A$ (Sundanese translation). Another version can be found as an application in Google Play. It is not surprising if another version of translation will probably be found again.

From translation studies perspective, these translation versions of al-Lujain ad-dān $\bar{\imath}$ are interesting to be deeply investigated, especially in terms of the techniques, methods, and ideology of translation used and adopted by the translators. That is because each of these translation versions has its own uniqueness. There are translation versions in which the translators do more than their positions as the translators. Most of them give additions or more explanations in the target language, which were not found in the source language. Thus, they are not only the translators but also likely to be the second authors of the book. This uniqueness of these translation versions of al-Jailān̄̄'s hagiography is the primary focus in this study.

Because of the many translation versions of the book, this study prefers to pay more attention to Javanese versions that use Pegon script, rather than Indonesian versions. The reason is that these Javanese versions of translation are written by the Kyais (the Islamic traditional leaders) who have higher reputation among their followers because of their knowledge about Islamic teachings and Arabic language. Most of them are also pesantren leaders and spiritual leaders (murshid) of tarekat. Another reason is that these Javanese versions of translation have been published since 1950's, and have been reprinted many times until today; for example, Lubāb al-ma 'ān̄ by Abi Shaleh Mustamir. In fact, the Javanese traditional Muslims always need these Javanese versions of translation to be used in their ritual called manaqiban.

Finally, an-Nūr al-burhāni fì tarjamati allujain ad-dān̄i written by Muslih al-Marāqī, one of the Javanese versions of al-Lujain ad-dān $\vec{\imath} \mathrm{s}$ translations, is chosen as a sample of this study, for its popularity among other Javanese versions and extensive use in manaqiban ritual at several places (Budianto, 2016; Rohmadi, 2012; Ta'rifin, 2009). Specifically, this study is committed to answer the research questions i.e. first, what is the content of an-Nūr al-burhānī fì tarjamati al-lujain ad-dānī? Second, what techniques does the translator apply? Third, what methods does the translator choose? Fourth, what ideology of translation does the translator adopt? By answering these research questions, the uniqueness of the translation version of al-Jailān̄̄ss hagiography can be explained comprehensively.

Technique, Method, and Ideology of Translation Translating consists in reproducing the receptor language in the closest natural equivalent of the source-language message, first in terms of meaning, secondly in terms of style (Nida \& Taber, 1982). In other words, translating can be simply defined as transferring the message from the source language (SL) into the target language (TL), both in terms of meaning and style. The concept of equivalence has been of particular concern to translation scholars since it has been inextricably linked with both definitional and practical aspects of translating. Being an essential feature of translation theories in the 1960s and 1970s, equivalence was meant to indicate that source text (ST) and target text (TT) share some kind of "sameness" (Panou, 2013).

In fact, it is impossible to really produce a TT which is precisely the same as the ST in terms of meaning and style, because two languages are different linguistically and culturally. The translation can never be completely adequate to the foreign text. A portion of source texts may not be translated. It is what the expert calls untranslatability. However, the translator can use several techniques and methods to solve this untranslatability. It is true that heated discussions among translation scholars about the terms of technique and method in translation studies have been going until now, but finally this study agrees with some definitions of terms proposed by Molina and Albir (2002).

According to Molina and Albir, translation method refers to the way a particular translation 
process is carried out in terms of the translator's objective, i.e., a global option that affects the whole text. Several translation methods may be chosen, depending on the aim of the translation: interpretative-communicative (translation of the sense), literal (linguistic transcodification), free (modification of semiotic and communicative categories) and philological (academic or critical translation). The translation method affects the way micro-units of the text are translated: the translation techniques. Thus, we should distinguish between the method chosen by the translator, e.g., literal or adaptation, that affects the whole text, and the translation techniques, e.g., literal translation or adaptation, that affect micro-units of the text (Molina \& Albir, 2002).

Meanwhile, the translation techniques can be defined as procedures to analyze and classify how translation equivalence works. There are several techniques i.e. adaptation, amplification, borrowing, calque, compensation, description, discursive creation, established equivalent, generalization, linguistic amplification, linguistic compression, literal translation, modulation, particularization, reduction, substitution, transposition, and variation (Molina \& Albir, 2002). Another scholar makes a simpler category: structural and semantic. Structural technique consists of addition, subtraction and transposition, whereas semantic technique includes the following: borrowing, cultural equivalent, descriptive equivalent, synonym, official translation, reduction and expansion, addition, deletion, and modulation (Suryawinata \& Hariyanto, 2003).

It is necessary to note that no translator applies only one method or technique in translating. At least, he practices the combination of two methods or more. The analysis of methods practiced by the translator will be concerned about what ideology is adopted by him. The ideology in translating may be defined as the tendency, consideration, and interest of the translator in choosing and practicing translation methods and techniques. It is the translator's orientation to the source culture or target culture, so it can be classified into two tendencies: foreignization and domestication.

The term "foreign" in foreignizing translation "is not a transparent representation of an essence that resides in the foreign text and is valuable in itself, but a strategic construction whose value is contingent on the current target-language situation" (Venuti, 2004, p. 20). Generally, domestication "designates the type of translation in which a transparent, fluent style is adopted to minimize the strangeness of the foreign text for target language readers", while foreignization means "a TT is produced which deliberately breaks target conventions by retaining something of the foreignness of the original" (Shuttleworth \& Cowie, 2014, pp. 44 \& 59).
The study of translation as a product has been carried out by many researchers in various types of text and fields, such as medicine (Silalahi, 2009), literary (Siregar, 2015), Holly Koran (Anshori, 2016), censorship (Yuliasri, 2017), translation training (Karnedi, 2015), Javanese translation from Bidāyah al-hidāyah written by al-Ghazāli (Anis \& Saddhono, 2016), and use of Arabic-Javanese books in Islamic education (Munip, 2016). In fact, alJailān̄̄'s hagiography has been studied from a political perspective (Saerozi, 2007; Sahri, 2011) instead of its translation; hence, this study is focused on describing the technique, method, and ideology of translation adopted by the translator.

\section{METHOD}

The qualitative-case study is chosen as the procedure for doing this study. Qualitative research concerns providing description of a phenomenon that occurs naturally. Therefore, the data in this study are words, phrases, and sentences in both ST (al-Lujain ad-dāni) and TT (an-Nūr al-burhānī). Purposive sampling is also chosen as a technique for collecting data appropriate to the research questions, i.e. the examples of TT are identified based on the tendency of techniques, methods, and ideology adopted by the translator, and then they are ready to be analyzed. Volume 2 of an-Nūr al-burhānī is the primary source of data. Meanwhile, qualitative content analysis is applied for analyzing data in relation to their contexts. Qualitative content analysis is a research method for the subjective interpretation of the content of text data through the systematic classification process of coding and identifying themes or patterns.

This study applies the procedure of analysis i.e. first, content structuring or theme analysis, which was meant to filter out from the material specific content dimensions and to summarize this material for each content dimension. Second, typebuilding content analysis, which was meant to classify and describe a heterogeneous amount of material. This stage consists of six steps, i.e. definition of the dimension(s) of type-building; definition of the logic of typology (extreme types, frequent types, theoretically interesting types); inductive category development with those two aspects as category definition; revising the inductive categories (types) and determining the ultimate typology; choosing representatives for the types; and describing those types by summarizing qualitative content analysis or inductive category formation.

\section{FINDINGS AND DISCUSSION \\ The Contents of an-Nūr al-Burhānī}

An-Nūr al-burhān̄i consists of two volumes; volume 1 contains 108 pages, while volume 2 contains 127 
pages. Both volumes are published by Karya Toha Putera Semarang in 1962 and printed without table of contents. Several kyais (traditional Islamic leaders) gave their best appreciation to the book, as documented in the front pages of volume 1 . This volume is an introduction written by the translator, in which he speaks about several terms related to the legal status of manāqib (ritual for reading a saint's hagiography), tawāsul (mediation in praying), khawāriq al-ādāt (extraordinary), karāmah (miracles) of saints, definition of saint, and manual for doing manāqib. The translator prefers to use the question-answer style for describing the topics above rather than narration style.

Meanwhile, volume 2 is the Javanese translation from Arabic al-Lujain ad-dāni. Both ST and TT are presented in one page. The ST is located on the top part of the pages, while the TT is located on the bottom, separated by a line. The TT is written in Pegon script with syakal (attributes) and smaller than the size of ST. It is often found, however, that the ST and TT presented in one page do not match. Under TT, the translator often adds a line where he inserts footnotes to describe about something in ST. Surprisingly, all of the footnotes are written in Arabic, not Javanese.

It is necessary to know that the Arabic alLujain ad-dāni takes the form of prose, tends to be hyperbolic in meaning, and all of its sentences are ended with a rhyme. The purpose of using rhymes is to bring the readers or listeners of this hagiography to the feeling of goodness like when they read or listen to the Holy Koran. In addition, in this hagiography, the author inserts shi' $r$ (Arabic poems), in which he describes about the ancestors of Shaikh 'Abd al-Qādir al-Jailāni. This shi' $r$ is practically read by all participants in manāqib ritual with a certain rhythm. In each of the chapters, the author begins with a beautiful sentence of prayer, that is usually read together in manāqib ritual. This prayer is Allāhumma unshur nafhāti ar-rị̣wān 'alaihi. Wa amiddanā bi al-asrāri al-latī auda 'tahā ladaihi (O Allah, please spread Your fragrant contentment for him, and please give me the secrets that You have given to him).

Although the prayer above is poetic in style, the translation is in prose and longer than the ST. To cite an example, "Ya Allah mugi Panjenengan kersa gelar ing gandaarume karidan Panjenengan dateng Kanjeng Shaikh 'Abd al-Qādir al-Jailāni radidyallāhu 'anhu. Saha malih mugi Panjenengan kersa paring dateng kula ing asrār ingkang sampun Panjenengan selap wonten ing ngarsanipun Kanjeng Shaikh 'Abd al-Qādir al-Jailāni radiyallāhu 'anhu'. (O Allah, please spread Your fragrant contentment for Shaikh "Abd al-Qādir alJailāni raḍiyallāhu 'anhu. In addition, please give me the secrets that You have given to Shaikh 'Abd al-Qādir al-Jailāni raḍiyallāhu 'anhu).
This hagiography does not seem chronological in talking about al-Jailānī's journey of life, except in the first and the end of the book, where the author describes his birth and death, while the events between his birth and his death are narrated randomly. After introduction, the author begins his book with narrating about the birth of al-Jailānī and his ancestors that connect to Prophet Muhammad via his beloved daughter, Fatimah. It is believed that al-Jailānī has shown his miracles from early childhood, when he did not want to suckle his mother in Ramaḍān (Al-Marāqī, 1962b). The next narration is about al-Jailānī's teachers, and how he pursued all branches of Islamic knowledge from several reputable ulemas and then lived in the deserts of Iraq for 25 years, where he did not meet anyone else. In his first visit to Iraq, he met Prophet Hị̣̂ir although al-Jailānī did not know about him. In this meeting, Hị̣ir required al-Jailān̄i not to contradict him, and commanded al-Jailānī to "sit down here, and don't move from your place!", and then al-Jailānī sat down there for 3 years (AlMarāqī, 1962b, pp. 28-30). This story is similar to Sunan Kalijaga's story that circulates among Javanese people.

The next pages are decorated by some narrations about other al-Jailān̄̄'s miracles, like his capability to answer all questions of a group of ulemas that are still kept in their hearts (Al-Marāqī, 1962b, pp. 32-33), refuse the distractions of a jin who claimed to be God (Al-Marāqī, 1962b, pp. 4546), put a rooster back to life (Al-Marāqī, 1962b, p. 59), help people remotely from his madrasah (AlMarāqī, 1962b, pp. 61-65), treat sick people disturbed by a jin (Al-Marāqī, 1962b, pp. 65-66), deflect the taqdīr of Abu al-Mudaffar through his prayer and others (Al-Marāqī, 1962b, pp. 68-72), cancel the flying ability of a saint who is arrogant (Al-Marāqī, 1962b, pp. 74-75), travel a long distance in a short time (Al-Marāqī 1962b, pp. 7682). The political attitude of al-Jailānī against the ruler is also spoken (Al-Marāqī, 1962b, pp. 82-87). The author also inserts al-Jailānī's sayings or advice to his followers, and closes the book with sentences of prayer recommended to be recited after reading the book.

The abundant stories in this book that do not make sense cause some people to doubt its truthfulness. Moreover, some consider it merely a made-up story of its author, because it does not fit al-Jailānī's personality and writings. However, the supporters of the truthfulness of al-Jailānī's miracles also have the arguments that the miracles of the prophets can possibly be possessed by saints like alJailānī. They believe that Holy Koran describes about the miracles of ordinary people in addition to the prophets', like those of Ashab al-kahfi, Maryam, Dhu al-Qarnain, and others (Al-Marāqīe 1962a, pp. 78-82). 


\section{Technique of Translation}

In this section, the samples of TT are described and then analyzed based on the techniques of translation adopted by the translator. Factually, the translator has adopted several techniques of translation that can be seen in the following subsections.

\section{Calque or literal translation}

This technique can be defined as to translate a word or an expression word for word, and corresponds to Nida's formal equivalent (Molina \& Albir, 2002).

Table 1: The examples of calque or literal translation application

\begin{tabular}{|c|c|}
\hline Javanese Translation & Arabic Text \\
\hline $\begin{array}{l}\text { Mangka ngendika tiyang ingkang sanget hajate dateng fadale } \\
\text { Allah kang luma tur nyelametaken (para mukminin sangking } \\
\text { siksa, ingkang nami sayyid) Ja'far bin Hasan bin 'Abdul Karim } \\
\text { al-Barzanji (mekaten). }\end{array}$ & [1] فيقول المفتقر إلى فضل الكريم البرزنجي. الكريم المنجى جعفر بن حسن \\
\hline $\begin{array}{l}\text { Lan disebut yen Kanjeng Shaikh siji tempo mirsani nur kang } \\
\text { agung tur madangi jajahan, banjur ana ing kono katon rupa } \\
\text { kang undang-undang mengkene. }\end{array}$ & 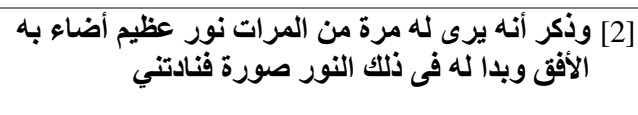 \\
\hline
\end{tabular}

Example [1] shows that all of words and phrases in ST are translated into TT literally. Moreover, the structure of TT is affected by the structure of ST, so it is not natural in Javanese language. Subject in Javanese is usually located in the beginning of a sentence, but in "mangka ngendika tiyang ingkang sanget hajate dateng fadale Allah..." the subject (tiyang ingkang sanget hajate dateng fadale Allah) is located after the predicate (ngendika). The natural Javanese sentence must be "Tiyang ingkang sanget hajate dateng fadale Allah ngendika." or in English, "A man who really needs Allah's mercy said." In example [2], the translator also practices literal translation technique, because all Arabic words are translated to Javanese literally, and the structure is still influenced by Arabic syntax.

\section{Description technique}

It is to replace a term or expression with a description of its form or/and function (Molina \& Albir, 2002), and the samples can be seen in table 2 .

Table 2: The examples of description technique application

\begin{tabular}{|c|c|}
\hline Javanese Translation & Arabic Text \\
\hline wali kutub (punjere jagad) ahli ma 'rifat ing Allah & [3] القطب الربانى \\
\hline $\begin{array}{l}\text { ahli nulungi dateng tiyang sami tawasul/ dipun seja kedamel } \\
\text { mutawassal bih kaliyan para mutawassilin }\end{array}$ & [4] الغوث الصمدانىّ \\
\hline
\end{tabular}

Hai Syetan kang dilaknati/ kang didohaken sangka rahmate Allah, sira [ ] ngadoha sangka ingsun! (Aja marek-marek marang ingsun!)

From examples [3], [4] and [5], it can be concluded that the translator gives descriptions for several terms والغوث الصمدانيّ ,القطب الربانى and لعين. All descriptions are the Sufi's terms in which the translator is very competent. In the next pages of his work, the translator always gives clear descriptions to the terms that need elaboration

\section{Borrowing technique}

It is to take a word or expression straight from another language. It can be pure (without any change) or it can be naturalized (to fit the spelling rules in the TL). The translator often practices pure borrowing technique and naturalized-borrowing technique. He borrows at least 107 Arabic words or phrases to TT. Sometimes, the translator mixes Arabic and Javanese words. The examples of pure Arabic borrowed words are ilm latīfah, ummat alijābah, ba'd arbāb at-țarīqah al-mu'tabarah, kāmilīn, asrār rabbānniyah, raḥmat ilāhiyah, shaikh ath-thaqalain, wușul ilā llāh, khawāriq al- 'ādāt, alārif billāh, khirqah șüfiyah, arādhil, shahwāt shaițāniyah, mujāhadat an-nafs, firāq, tawajjuh, murāqabah, bi 'ināyatillāh, mas'alah mushkilah, taslìm, imtithāl, intiqāl, li at-tahadduth bi anni'mah, abdāl, nuktah lațīfah, mu'abbir, yaum al'arḍ wa al-hisāb, mujālasah, maqām shuhūd li alaghyār, maqām baqa' ma 'nafsihi, maqām indirāj fí däirah hissiyah and others. Meanwhile, the examples of mixing Arabic and Javanese words are iftaipun, shughulaken, khādime, nur jamale Allah, badale, hujjahe Allah, tarīqipun, futūhipun and others.

\section{Amplification or addition}

This technique is used to introduce details that are not formulated in ST: information, explicative paraphrasing. It is similar to addition technique. Footnotes are a type of amplification (Molina \& Albir, 2002); for example: 
Table 3: The examples of amplification or addition technique application

\begin{tabular}{|c|c|}
\hline Javanese Translation & Arabic Text \\
\hline 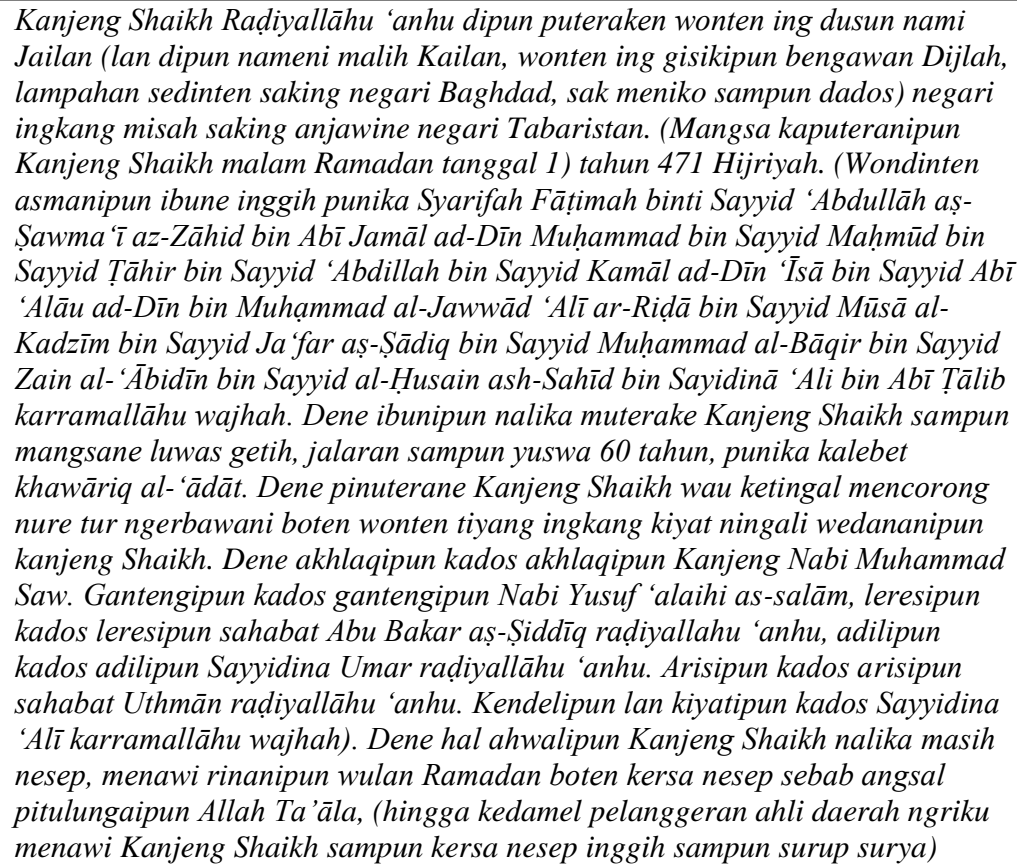 & 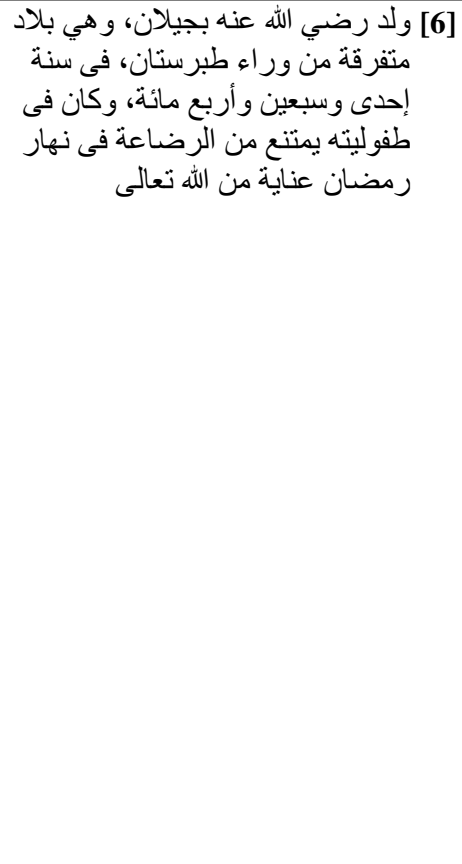 \\
\hline
\end{tabular}

The TT in example [6] above is lengthier than the ST, and the sentences in the parentheses are added by the translator, as additional information to TT readers which includes al-Jailānī's place of birth, date of birth, his mother's lineage, age of his mother when she was pregnant, and his personality. Not all of this information is mentioned in ST. If the translator just translates what is stated in ST above, the TT is only translated into "Shaikh Radiyallāhu 'anhu was born in Jailān, a village outside Tabaristan in $471 \mathrm{AH}$. When he was in his childhood, he did not want to suck during the days of Ramadan, since it is a help from Allah". The translator very commonly uses the amplification technique. It can be seen on pages $29,34-36,46,51-$ $55,79,89-93,97$, and 104-105 of an-Nūr alburhānī. Moreover, there are 35 footnotes in the book.

\section{Adaptation technique}

It is to replace an ST cultural element with one from the target culture (Molina \& Albir, 2002). The translator also uses this technique for translating several words. See table 4.

Table 4: The examples of adaptation technique application

\begin{tabular}{|c|c|}
\hline Javanese Translation & Arabic Text \\
\hline wananipun tanah Iraq & [7] صخراء العراق \\
\hline manuk emprit & [8] لعصفور \\
\hline manuk peksi & [9] الحدأة \\
\hline pucuke lantingan, kendi, poci & [10] الإبريق \\
\hline
\end{tabular}

Example [7] صخراء العراق is translated as wananipun tanah Iraq (the forest of Iraq), whereas the lexical meaning is desert of Iraq. The translator replaces desert with forest, because the Javanese people know more about forests than they do about desserts. The translator also translates [8] الحدأة [9] [8 [into manuk emprit (the emprit bird); into manuk peksi (the peksi bird); and [10] الإبريق into pucuke lantingan, kendi, poci. All of these Javanese words are familiar in Javanese culture.

\section{Method of Translation}

The continuous use of calque, literal, and borrowing techniques in translating al-Lujain ad-dāni indicates that the translator applies the methods oriented to $\mathrm{ST}$, i.e. literal (linguistic transcodification). Based on qualitative content analysis, the translator most often produces a TT that is structurally affected by the ST, since it is not natural in Javanese grammar or structure. But all of words, phrases, clauses, and sentences of Arabic text are translated into Javanese fully. The translator never applies the deletion technique. On the other hand, the translator also uses description, amplification-addition and adaption techniques in his work. Therefore, the translator attempts to apply interpretativecommunicative (translation of the sense) method that is oriented to TT. It is proved by the abundance of additional information and footnotes in the book that indicate the translator's hopes for his work to be fully understood by readers of the target language. 


\section{Ideology of Translation}

Based on analysis of techniques and methods applied by the translator above and based on the number of words borrowed from Arabic, it is clear that the translator is an adherent of foreignization ideology. He always transmits all of the messages in the ST into TT. Based on observed data, most of words, phrases, and sentences in ST are translated into TT fully. It is easy to understand that applying the word-by-word and literal translation will carry out all aspects of structures and meanings of ST. If the equivalents for the Arabic words or phrases in ST are not found in Javanese language, the translator always uses the borrowing technique. About 107 Arabic words or phrases are registered in TT. Actually, most of the Arabic words or phrases found in ST can be traced for their equivalents in Javanese language, if the translator wants to do it. For example, the word mujālasah (p. 54) can be translated into Javanese lungguhan sesarengan (sitting or meeting together). However, the translator chooses to borrow Arabic words rather than using Javanese words. Therefore, that the translator has adopted foreignization ideology cannot be debated.

However, it cannot be denied that the translator has attempted to make the readers understand his translation. He said, "pramila kula anggep penting umpami dipun terjemahaken kanti tembung daerah Jawa mriki, supados tiyang awam sak sami kula, saged mangertosi artosipun" (so, I think it is important if the book is translated into current Javanese language, so the common people like me can understand its meaning) (Al-Marāqī, 1962a, p. 9). His statement is proved by the application of several techniques and methods that are oriented to TL, such as the amplification-addition and adaption techniques and the interpretative-communicative (translation of the sense) method, but the resulting TT is still influenced by the structure of Arabic as SL. Therefore, the translator does not really adopt the domestication ideology in his translation.

\section{CONCLUSION}

$A n-N \bar{u} r$ al-burhānī is the Javanese version of alJailānī's hagiography that has gained extreme popularity, especially among Javanese Muslims. The first volume of the book is an introduction, while the second volume is a translation of the alLujain ad-dāni. This book deals with the life of alJailānī that is full of miracles, besides his teachings and advice. The findings of this study prove that the translator has implemented various techniques of translating such as calque, description, borrowing, amplification-addition and adaption techniques. In fact, the translator has tried to make the TT easily understood by Javanese people, but he has failed to do so. He tends to apply the literal (linguistic transcodification) method rather than the interpretative-communicative (translation of the sense) method. As a result, the TT is still influenced by the structure of Arabic as SL and not natural in everyday use of Javanese language. Thus, it can be inferred that the translator more dominantly adopts the ideology of foreignization than domestication. However, what the translator does is more advanced than the other Javanese translators, who usually use only the word for word or literal translation method. This is the translator's uniqueness in translating alJailān̄̄'s hagiography or manāqib.

\section{REFERENCES}

Ad-Duhaibi, A. al-M. (2007). Itḥāf al-akābir fì sīrah wa-manāqib al-imām Muhȳi al-Dīn 'Abd alQādir al-Jīlānī al-Hasañ̄ al-Husayn̄̄ waba "ḍ mashāhīr dhurrīyatihi ulī al-faḍl wa-alma"äthir (Unpublished master's thesis). Cairo: Dar al-Kutub al-Ilmiyah.

Al-Gailani, N. (2016). The Shrine of Abd al-Qädir al-Jīlāni in Baghdad \& the Shrine of Abd alAzìz al-Jīlānì in Aqra: Mapping the multiple orientations of two Qādirī Sufi shrines in Iraq (Doctoral Thesis). University of Glasgow, United Kingdom.

Al-Kailān̄i, J. ad-D. F. (2014). Jaghrāfiyat al-Bāz al-Ashhāb. Pes Marocco: Al-Munadzammah al-Maghrïbiyyah li at-Tarbiyyah wa athThaqāfah wa al-'Ulūm.

Al-Marāqī, M. (1962a). An-Nūr Al-Burhāni Fi Tarjamah Al-Lujain Ad-Dānī Vol. 1. Semarang: Toha Putera.

Al-Marāqī, M. (1962b). An-Nūr Al-Burhāni Fi Tarjamah Al-Lujain Ad-Dānī Vol. 2. Semarang: Toha Putera.

Anis, M. Y., \& Saddhono, K. (2016). Arab-Jawa sebagai sebuah upaya (indigenous language): Studi kasus dalam penerjemahan kitab bidayatul-hidayah karya Imam Al-Ghazali. Akademika, 21, 36-47.

Anshori, D. S. (2016). Gender cognition in religious discourse: A study of framing in thematic Holy Koran interpretation. Indonesian Journal of Applied Linguistics, 6(1), 88-98. https://doi.org/dx.doi.org/10.17509/ijal.v6i1.2 741

Budianto, A. (2016). Resepsi terhadap Ayat-ayat alQuran pada Manaqib Syaikh Abd al-Qadir alJailani dalam Kitab al-Nur al-Burhani fi Tarjamati al-Lujain ad-Dani (Studi Kasus Jama 'ah Masjid Aolia, Dusun Panggang III, Desa Giriharjo, Kecamatan Panggang, Kabupaten Gunungkidul) (Master's thesis). UIN Sunan Kalijaga, Yogyakarta.

Esposito, J. L. (2017). The Oxford dictionary of Islam. Retrieved from www.oxfordislamicstudies.com/article/opr/t12 $5 / \mathrm{e} 767$

Fikri, I. (2014). Aksara pegon: Studi tentang simbol 
perlawanan Islam Jawa abad XVIII-XIX.

LP2M IAIN Walisongo, Semarang.

Karnedi. (2015). Translator training by distance learning - A dual approach. Indonesian Journal of Applied Linguistics, 5(1), 134-145. https://doi.org/dx.doi.org/10.17509\%2Fijal.v5 i1.840

Molina, L., \& Albir, A. H. (2002). Translation techniques revisited: A dynamic and functionalist approach. Meta, XLVII(4), 498512.

Munip, A. (2016). Tracing the history of the ArabicJavanese language translation books in Nusantara Islamic Education. Jurnal Pendidikan Islam, 5(1), 43-67. https://doi.org/10.14421/jpi.2016.51.43-67

Najih, A. A. (1997). Terjemah Maulid al-Barzanji. Jakarta: Pustaka Amani.

Nida, E. A., \& Taber, C. R. (1982). The theory and practice of translation (Vol. VIII). Leiden: E.J Brill.

Panou, D. (2013). Equivalence in translation theories : A critical evaluation. Theory and Practice in Language Studies, 3(1), 1-6. https://doi.org/10.4304/tpls.3.1.1-6

Rohmadi. (2012). Rasionalitas anggota Jama 'ah Manaqib: Studi deskriptif Manaqib di Pondok Pesantren Al-Qodiri Desa Gebang Poreng Patrang Jember (Unpublished master's thesis). Universitas Jember, Jember.

Saerozi, M. (2007). Pelajaran politik Manaqib Sufiyah: Telaah terhadap Kitab Al-Lujjain AlDani. Profetika Jurnal Studi Islam, 9(2), 142157.

Sahri. (2011). Dimensi politik dalam ajaran-ajaran Tasawuf: Studi kasus atas Manaqib Syaikh
'Abd al-Qadir al-Jailani. Asy-Syir'ah Jurnal Ilmu Syari'ah Dan Hukum, 45(2).

Shuttleworth, M., \& Cowie, M. (2014). Dictionary of translation studies. New York: Routledge.

Silalahi, R. (2009). Dampak teknik, metode, dan ideologi penerjemahan pada kualitas terjemahan teks medical-surgical nursing dalam Bahasa Indonesia (Unpublished master's thesis). Universitas Sumatera Utara, Medan.

Siregar, R. (2015). Translation Ideology in the translation process of Stephen R . Covey's The $8^{\text {th }}$ Habit into Indonesian. Internaional Journal of Comparative Literature \& Translation Studies, 3(4), 54-61. https://doi.org/10.7575/aiac.ijclts.v.3n.4p.54

Suryawinata, Z., \& Hariyanto, S. (2003).

Translation: Bahasan teori dan penuntun praktis menerjemahkan. Yogyakarta: Kanisius.

Ta'rifin, A. (2009). Tafsir budaya atas tradisi Barzanji dan Manakib. Jurnal Penelitian, 2(9), 1-14.

van Bruinessen, M. (2000). Shaykh 'Abd al-Qādir al-Jīlāinī and the Qadiriyya in Indonesia. Journal of the History of Sufism, 1(2), 361395.

Venuti, L. (2004). The translator's invisibility: A history of translation. New York: Routledge.

Yuliasri, I. (2017). Translators' censorship In English-Indonesian translation Of Donald Duck Comics. Indonesian Journal of Applied Linguistics, 7(1), 105-116. https://doi.org/dx.doi.org/10.17509/ijal.v7i1.6 863 